Metallophysics and Advanced Technologies

металофіз. новітні технол.

Metallofiz. Noveishie Tekhnol.

2021 , vol. 43 , No. 11 , pp. $1553-1562$

https://doi.org/10.15407/mfint.43.11.1553

Reprints available directly from the publisher
(C) 2021 G. V. Kurdyumov Institute for Metal Physics, National Academy of Sciences of Ukraine Published by license under the G. V. Kurdyumov Institute for Metal PhysicsN.A.S. of Ukraine Publishers imprint. Printed in Ukraine.

PACS numbers: 07.05.Kf, 44.10.+i, 64.60.-i, 64.75.-g

\title{
Thermophysical Properties of Aluminium of Grade A5N and Its Alloys Doped with Silicon, Copper and Rare-Earth Metals
}

\author{
B. N. Gulov, Z. Nizomov*, and F. S. Tabarov* \\ Tajik National University, Faculty of Physics, \\ 17 Rudaki Ave., \\ TJ-734025 Dushanbe, Tajikistan \\ "Dushanbe Branch of National University of Science and Technology MISiS, \\ 7 Nazarshoeva, \\ TJ-734012 Dushanbe, Tajikistan
}

The kinetics of cooling of the aluminium grade of the A5N, its alloys doped with silicon, copper, and rare-earth metals in a wide temperature range were measured. It revealed that the process of cooling of the aluminium and its alloys has a relaxation behaviour. An experimental study of the specific heat and heat transfer coefficient of these substances is carried out. According to experimental data, the temperature dependence of the heat transfer coefficient for pure metals is calculated. It is shown that the values of heat transfer coefficients of copper, aluminium, and zinc are different. To determine the heat capacity of doped alloys for each group is recommended to define the coefficient of heat transfer of the initial alloy.

Key words: aluminium A5N, cooling, specific heat capacity, coefficient of heat transfer.

Виміряна кінетика охолодження алюмінію марки $\mathrm{A} 5 \mathrm{~N}$, його стопів з кремнієм, міддю і рідкісноземельними металами у широкому інтервалі температур. Виявлено, що процес охолодження алюмінію і його стопів має релаксаційний характер. Проведено експериментальне дослідження питомої теплоємності і коефіцієнта тепловіддачі цих речовин. Одержані дані проведеного дослідження дозволили розрахувати температурну залежність коефіцієнта тепловіддачі чистих металів. Показано, що величини

Corresponding author: Bobomurod Nurovych Gulov

E-mail: gulovbobomurod@gmail.ua

Citation: B. N. Gulov, Z. Nizomov, and F. S. Tabarov, Thermophysical Properties of Aluminium of Grade A5N and Its Alloys Doped with Silicon, Copper and Rare-Earth Metals, Metallofiz. Noveishie Tekhnol., 43, No. 11: 1553-1562 (2021),

DOI: $10.15407 /$ mfint.43.11.1553. 
коефіцієнтів тепловіддачі для міді, алюмінію та цинку відрізняються. Для знаходження теплоємності легованих стопів для кожної групи рекомендовано визначати коефіцієнт тепловіддачі для вихідного стопу.

Ключові слова: алюміній $\mathrm{A} 5 \mathrm{~N}$, охолодження, питома теплоємність, коефіцієнт теплопередачі.

(Received April 4, 2020; in final version, September 8, 2021)

\section{INTRODUCTION}

The thermophysical properties of metals and alloys are the most important physical characteristics that determine the patterns of their behaviour under various operating conditions [1-11]. The main interest in doped alloys is primarily due to the possibility of significant improvement, and sometimes a fundamental change in the physicochemical properties of known materials.

The thermophysical properties of aluminium alloys doped with rareearth metals, scandium, and yttrium have been the subject of intensive study in recent years $[4,8,9,14]$. The range of their possible performance is almost unlimited. However, to date, there is no theory has been developed that accurately describes possible changes in thermophysical properties during the doping of alloys.

Thus, the experimental study of the thermophysical properties of doped alloys is a significant scientific and applied interest. The solution to this problem can contribute to the creation of materials with predetermined properties.

This paper presents the results of an experimental study of the temperature dependence of the specific heat capacity of an ultrahighpurity aluminium base AK1M2 alloy doped with praseodymium, neodymium, scandium, and yttrium. At least partially to fill the gap in the experimental study of their thermophysical properties depending on the temperature and concentration of the doping metals is carried out.

\section{OBJECT OF THE STUDY AND RESEARCH METHODS}

The objects of the study are aluminium of grades of A5N (99.999\%) and A7 (99.7\%), Si $(99.0 \%), \mathrm{Cu}(99.99 \%)$, and aluminium-based alloys of grades $\mathrm{AK} 1\left(\mathrm{Al}+1 \%\right.$ wt. $\left.\mathrm{Si}^{9}\right)$ and $\mathrm{AK} 1 \mathrm{M} 2(\mathrm{AK} 1+2 \%$ wt. $\mathrm{Cu})$ doped with praseodymium, neodymium, scandium, and yttrium in different mass proportions (Table 1). The choice of research objects is due to the possibility of using these alloys in various fields of science and technology.

For purely physical reasons, observation of monotonous change in the temperature of an object during the heating is extremely difficult 
due to the presence of many factors (voltage in the power supply network, the thermal conductivity of the environment, etc.). The most convenient and simple method is to use the 'cooling-mode' regime, which makes fewer errors during the experiment.

The specific heat capacity of materials is measured using the setup shown in Fig. 1. The device consisted of the electric furnace (1) mounted on a bench, which can move to the horizontal direction. The sample (2) with this is a cylindrical form $(h=30 \mathrm{~mm}, D=16 \mathrm{~mm})$, with a drilled channel at one end, into which thermocouple (3) inserted (Fig. 1). The ends of the thermocouple are connected to the Digital Multimeter UT71B 4 meter, which allowed the direct recording of the measurement results on a computer (7) in a table view. The accuracy of temperature measurement is $\pm 0.1^{\circ} \mathrm{C}$.

According to the Newton-Richmann law of cooling, the specific heat capacity of alloys in the wide temperature range is measured. A body having a temperature above ambient will be cooled, and the cooling rate depends on the heat capacity of the body $C$ and heat transfer coefficient $\alpha$. The amount of heat lost by a preheated body of mass $m$ when it is cooled by $d T$ degrees will be

$$
d Q=C m d T .
$$

Loss of energy occurs through the surface of the body. Therefore, we can assume that the amount of heat lost through the surface of the body over time will be proportional to time, surface area $S$, and the difference in body temperature $T$ and the environment $T_{0}: d Q_{S}=-\alpha\left(T-T_{0}\right) S d \tau$. If the body releases heat in such a way that the temperature of all its points changes identically, then equality will be true [7]:

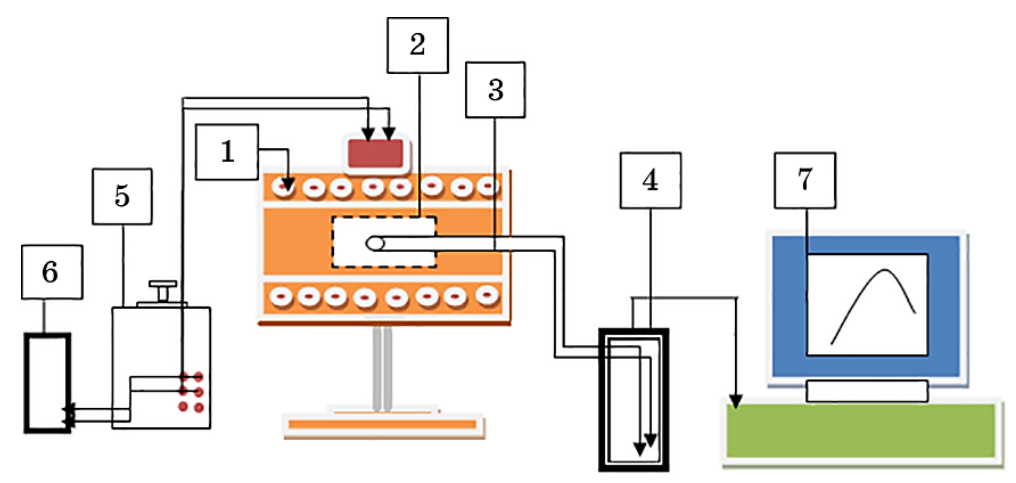

Fig. 1. Experimental setup for temperature measurements. 1-electric furnace; 2-sample; 3-thermocouple; 4-Digital Multimeter UT71B; 5-AC voltage controller; 6-Digital Multimeter DI 9208; 7 -computer. 


$$
C m d T=-\alpha\left(T-T_{0}\right) S d \tau .
$$

Heat transfer from a warmer body to a less warmed one is a tendency to establish thermodynamic equilibrium in a system consisting of many particles called a relaxation process. The relaxation process in time can be described as an exponential dependency.

In our case, a heated body transfers its heat to the environment (i.e. a body with an infinitely large heat capacity). Therefore, the ambient temperature can be considered constant $\left(T_{0}\right)$. Then the law of change in body temperature with time $\tau$ can be written as:

$$
\Delta T=\Delta T_{1} e^{-\tau / \tau_{1}},
$$

where $\Delta T$ is the difference in temperature between the heated body and the environment; $\Delta T_{1}$ is the difference in temperature between the heated body and the environment at the time of the beginning of the measurement. i.e. at $\tau=0, \tau$ is the cooling constant, numerically equal to the time during which the difference in temperature between the heated body and the environment decreases by a factor of $e$.

Assuming that in a short temperature range the values of $C, \alpha$, and $T$ are independent of the coordinates of the surface points of the samples heated to the same temperature, and at a constant ambient temperature, we write the ratio for two samples $C_{1} m_{1} S_{2} \alpha_{2}(d T / d \tau)_{1}=$ $=C_{2} m_{2} S_{1} \alpha_{1}(d T / d \tau)_{2}$. When using this formula for two samples having the same dimensions $s_{1}=s_{2}$ and the condition of the surfaces, the equality of their heat transfer coefficients $\alpha_{1}=\alpha_{2}$ is assumed. Therefore, knowing the masses of the samples $m_{1}$ and $m_{2}$, the cooling rates of the samples, and the specific heat capacity $C_{1}$, we can calculate $C_{2}$.

First, we needed to find out to what extent the assumption of $\alpha_{1}=\alpha_{2}$ is justified. For this, we studied the cooling process of copper, aluminium, and zinc, for which the temperature dependence of heat capacity is known. The experimentally obtained time dependences of the temperature of the samples are described with good accuracy by an equation of the form:

$$
T=y_{0}+a e^{-b \tau}+p e^{-k \tau},
$$

where $a, b, p$, and $k$ are constant values for a given sample. $y_{0}=T_{0}$ is the ambient temperature, $a=T_{1}-T_{0}, p=T_{2}-T_{0}$ is the amplitude of the first and second processes, the temperature difference between the heated body and the environment at the time the measurements begin, i.e. at $\tau=0, b=1 / \tau_{1}$, and $k=1 / \tau_{2}$, where $\tau_{1}$ and $\tau_{2}$ are the cooling constants for the first and second relaxation processes:

$$
T=T_{0}+\left(T_{1}-T_{0}\right) e^{-\frac{\tau}{\tau_{1}}}+\left(T_{2}-T_{0}\right) e^{-\frac{\tau}{\tau_{2}}} .
$$


Differentiating (2), we obtain the cooling rate:

$$
\frac{d T}{d \tau}=-\left(\frac{T_{1}-T_{0}}{\tau_{1}} e^{-\frac{\tau}{\tau_{1}}}+\frac{T_{2}-T_{0}}{\tau_{2}} e^{-\frac{\tau}{\tau_{2}}}\right) .
$$

\section{RESULTS AND DISCUSSION}

The experimentally obtained time dependences of the temperature of the samples are described with reasonably good accuracy by equation (2). Table 1 shows the values of the coefficients in formulas (2) and (3) for the investigated pure metals and alloys.

As an example, Fig. 2 shows the dependence of temperature on cooling time for copper, aluminium (A7), A5N, and AK1M2. The time dependence of the temperature of A5N shows on Figures 2 and 3 separately for the first and second relaxation process.

It should be noted that using the experimental data of cooling rates from equation (1), we only can determine the ratio of the heat transfer coefficient to the heat capacity of the sample

TABLE 1. Values of $T_{1}, \tau_{1}, T_{2}, \tau_{2},\left(T_{1}-T_{0}\right) / \tau_{1},\left(T_{2}-T_{0}\right) / \tau_{2}$ are for the studied metals and alloys.

\begin{tabular}{|c|c|c|c|c|c|c|c|}
\hline Alloy & $\begin{array}{c}T_{1}-T_{0}, \\
\mathrm{~K}\end{array}$ & $\begin{array}{c}\tau_{1}, \\
\mathbf{s}\end{array}$ & $\begin{array}{c}T_{2}-T_{0}, \\
\mathrm{~K}\end{array}$ & $\begin{array}{c}\tau_{1}, \\
\mathrm{~s}\end{array}$ & $\begin{array}{c}\left(T_{1}-T_{0}\right) / \tau_{1}, \\
\mathrm{~K} / \mathrm{s}\end{array}$ & $\left\{\begin{array}{c}\left(T_{2}-T_{0}\right) / \tau_{2}, \\
\mathrm{~K} / \mathrm{s}\end{array}\right.$ & $\begin{array}{c}T_{0}, \\
\mathrm{~K}\end{array}$ \\
\hline $\mathrm{Al}(\mathrm{A} 7)$ & 523.3 & 417 & 90.7 & 110 & 1.25 & 0.82 & 292.6 \\
\hline $\mathrm{Al}(\mathrm{A} 5 \mathrm{~N})$ & 411.8 & 526 & 208.4 & 154 & 0.78 & 1.35 & 295.2 \\
\hline $\mathrm{Cu}$ & 398.1 & 302 & 199.6 & 88 & 1.32 & 2.27 & 302.7 \\
\hline AK1 & 360.7 & 625 & 250.0 & 222 & 0.58 & 1.13 & 294.7 \\
\hline $\mathrm{AK} 1+\mathrm{Cu} 2 \%(1)$ & 420.4 & 500 & 211.8 & 189 & 0.84 & 1.12 & 286.4 \\
\hline & 470.1 & 476 & 182.6 & 178 & .99 & 1.02 & 291.0 \\
\hline & 448.1 & 500 & 221.6 & 196 & 0.90 & 1.13 & 286.4 \\
\hline & 416.5 & 500 & 265.5 & 238 & 0.83 & 1.11 & 289.3 \\
\hline & 352.4 & & 33 & & 0.63 & & 286.7 \\
\hline & 370.6 & 294 & 274 & 588 & 1.26 & 0.47 & 290.2 \\
\hline & 428.8 & 500 & 205 & 217 & .86 & & 293.1 \\
\hline & 358.2 & 278 & 302.7 & 588 & 1.29 & 0.51 & 285.5 \\
\hline & 457.5 & 500 & 232.0 & 204 & .91 & 1.14 & 288.1 \\
\hline & 0.6 & 312 & 246 & & .28 & & 284.2 \\
\hline & 361.0 & 303 & 279.0 & 666 & 1.19 & 0.25 & 286.4 \\
\hline & & 294 & $30^{\prime}$ & 66 & & & 288.0 \\
\hline & & & & 20 & 0.80 & 0.87 & 292.0 \\
\hline$+\mathrm{Y} 0.005$ & 322.0 & 263 & 307.1 & 588 & 1.22 & 0.52 & 281.5 \\
\hline & & 526 & 244.7 & 222 & 0.77 & & 286.2 \\
\hline & & 526 & 269 & 21 & 0.78 & 0.70 & 285.7 \\
\hline (1) + Y 0.5 & 512.6 & 454 & 112.6 & 161 & 1.13 & 0.70 & 292.3 \\
\hline
\end{tabular}




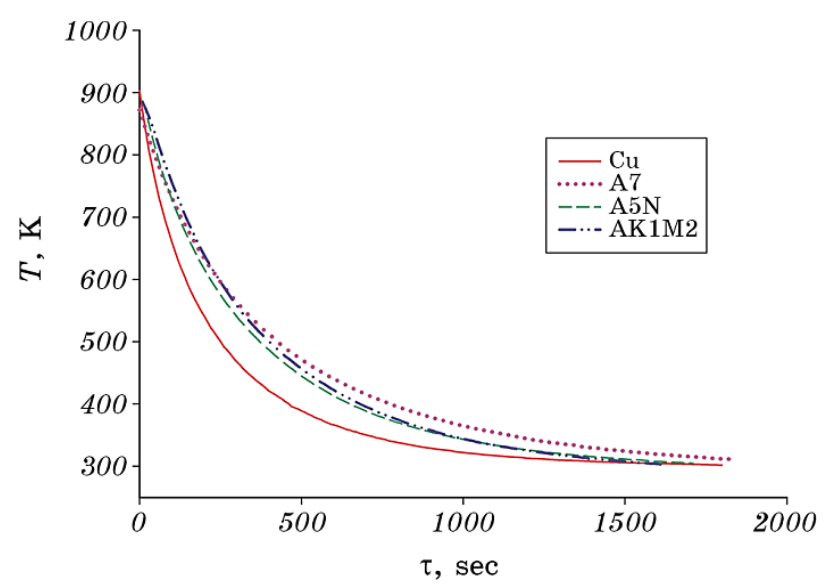

Fig. 2. Variation of the temperature of copper, aluminium A7 and A5N, alloy AK1M2 as a function of cooling time.

$$
\frac{\alpha(T)}{C(T)}=\frac{m(d T / d \tau)}{S\left(T-T_{0}\right)}
$$

It is known that the heat capacity can be calculated from the coefficient of heat transfer or vice versa. Figure 4 shows the relationship between the ratios of the coefficient of heat transfer to the heat capacity of different aluminium grades as a function of temperature.

The heat capacity of pure metals is measured by many authors, and their data are in good agreement with each other [16-19]. As a result

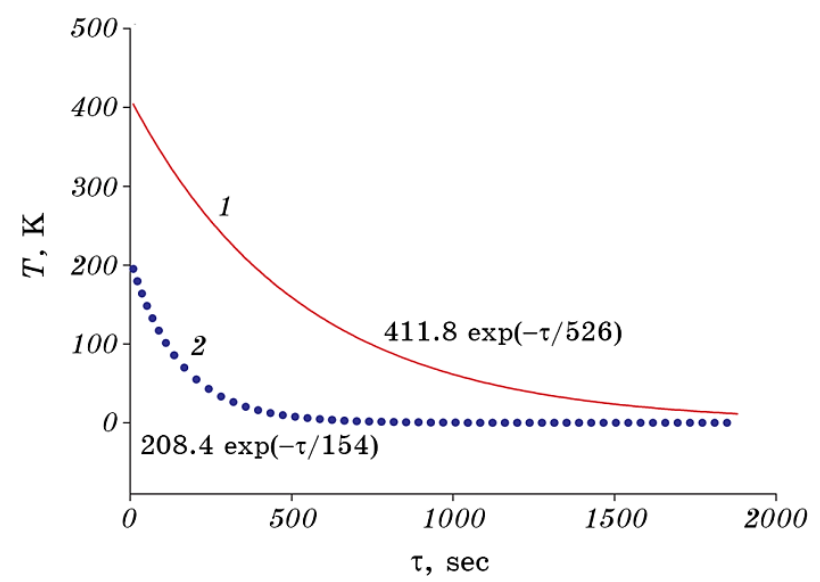

Fig. 3. Variation of the temperature of copper, aluminium A7, and A5N, alloy AK1M2 as a function of cooling time for first (1) and second (2) process. 
of data processing, we obtained the following equations for the temperature dependence of the specific heat capacity of copper, aluminium of the A5N grade and silicon in the temperature range of $293-873 \mathrm{~K}$, and zinc in the temperature range of $293-693 \mathrm{~K}$ :

$$
\begin{gathered}
C_{P}(T)_{\mathrm{Cu}}=310.53+36.0 \cdot 10^{-2} T-4 \cdot 10^{-4} T^{2}+2.2 \cdot 10^{-7} T^{3}, \\
C_{P}(T)_{\mathrm{A} 5 \mathrm{~N}}=730.23+0.7571 T-0.0008 T^{2}+5.97 \cdot 10^{-7} T^{3}, \\
C_{P}(T)_{\mathrm{Si}}=390.18+1.60 T-18 \cdot 10^{-4} T^{2}+7.24 \cdot 10^{-7} T^{3}, \\
C_{P}(T)_{\mathrm{Zn}}=325.44+36.9 \cdot 10^{-2} T-7 \cdot 10^{-4} T^{2}+7.6 \cdot 10^{-7} T^{3} .
\end{gathered}
$$

Using data on the specific heat and experimental values of the cooling rate, we calculated the temperature dependence of the heat transfer coefficient by the following formula

$$
|\alpha(T)|=\frac{C(T) m\left(\frac{d T}{d \tau}\right)}{S\left(T-T_{0}\right)} .
$$

Figure 5 shows the heat transfer coefficient of copper, aluminium, grade $\mathrm{A} 5 \mathrm{~N}$, and zinc as a function of temperature $T$.

According to the obtained data of the study, it possible for the first time to calculate the temperature dependence of the heat transfer coefficient for pure metals.

As can be seen, the values of the heat transfer coefficients for copper, aluminium, and zinc are different. Therefore, to determine the heat capacity of doped alloys for each group, it is necessary to deter-

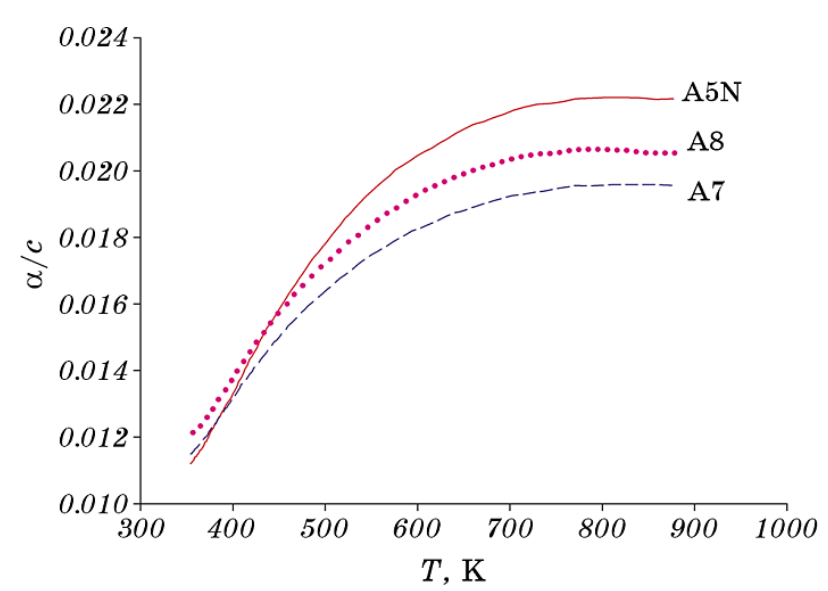

Fig. 4. The temperature dependences of the ratio of heat transfer coefficient to specific heat $\left(\mathrm{kg} /\left(\mathrm{m}^{2} \cdot \mathrm{s}\right)\right)$ for aluminium grades $\mathrm{A} 5 \mathrm{~N}, \mathrm{~A} 8$, and $\mathrm{A} 7$ on temperature. 
mine the heat transfer coefficient for the initial alloy.

Using the Neumann-Kopp rule, according to which the molar heat capacity of the compound is equal to the sum of the heat capacities of the components:

$$
C_{P}=x_{1} C_{1}+x_{2} C_{2},
$$

where $x_{1}$ and $x_{2}$ are the mass fractions of the components, the heat capacity of the alloys is calculated.

Then, applying the formula (4), the heat transfer coefficient for the alloy is calculated. From our knowledge, the information on the thermodynamic properties of AK1 and AK1M2 alloys is not available in the literature.

Upon the calculated data on the heat capacity of the AK1 and AK1M2 alloys, and the experimentally obtained values of the cooling rate, the following equations are obtained for the temperature dependence of the heat transfer coefficient:

$$
\begin{aligned}
& |\alpha(T)|_{\text {(AK1) }}=2.0591+0.0298 T-4.3362 \cdot 10^{-6} T^{2}+1.1254 \cdot 10^{-9} T^{3}, \\
& |\alpha(T)|_{\mathrm{AK} 1 \mathrm{M} 2}=8.4799+0.0127 T+1.9817 \cdot 10^{-5} T^{2}-1.0021 \cdot 10^{-8} T^{3} .
\end{aligned}
$$

The obtained experimental results for the heat transfer coefficient of the AK1 alloy show that even with small additions of the second component, the heat transfer coefficient cannot be considered as the same.

For AK1M2 doped alloys, the heat transfer coefficient is used for the initial alloy of AK1M2, if it does not depend on the concentration of the doping component. Next, we calculated the specific heat of doped alloys according to the formula $[14,15]$ :

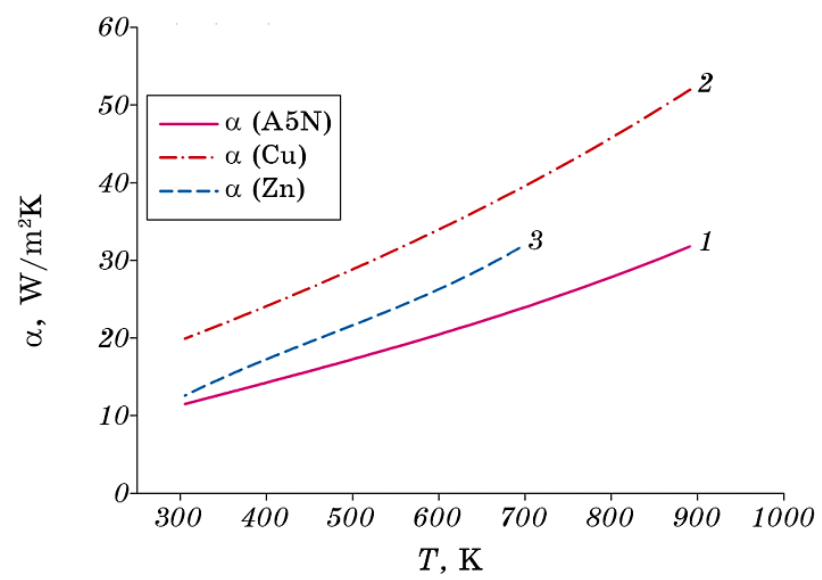

Fig. 5. The temperature dependencies of the heat transfer coefficient of aluminium grades A5N (1), copper (2), and zinc (3) on temperature. 
TABLE 2. The value of the coefficients in the equation $C_{P}(T)=a_{0}+b_{0} T+c_{0} T^{2}+d_{0} T^{3}$.

\begin{tabular}{|c|c|c|c|c|}
\hline Metal and alloys & $a_{0}$ & $b_{0}$ & $c_{0}, 10^{-4}$ & $-d_{0}, 10^{-6}$ \\
\hline $\mathrm{Al}(\mathrm{A} 5 \mathrm{~N})$ & 730.2302 & 0.7571 & -8 & -0.60 \\
\hline $\mathrm{Cu}$ & 310.5300 & 0.3600 & -4 & 0.22 \\
\hline $\mathrm{Si}$ & 390.1809 & 1.5987 & -18 & 0.72 \\
\hline $\mathrm{Sc}$ & 463.5476 & 0.5450 & -8 & -0.52 \\
\hline $\mathrm{Y}$ & 278.2143 & 0.0604 & 0.18 & - \\
\hline Pr & 174.5357 & -0.0071 & 2 & 0.06 \\
\hline $\mathrm{Nd}$ & 95.2619 & 0.4487 & -6 & -0.38 \\
\hline AK1 & 726.9297 & 0.7655 & -8.1 & -0.60 \\
\hline AK1M2 (1) & 718.6017 & 0.7574 & -8.02 & -0.59 \\
\hline (1) $+\mathrm{Nd} 0.005$ & 728.3789 & 0.19748 & 8.2 & 0.48 \\
\hline (1) $+\mathrm{Nd} 0.05$ & 719.2733 & 0.268 & 6.3 & 0.49 \\
\hline$(1)+\mathrm{Nd} 0.1$ & 656.145 & 0.9447 & -7.2 & -0.38 \\
\hline (1) + Nd 0.5 & 682.0345 & 0.5389 & 4.3 & 0.51 \\
\hline (1) $+\operatorname{Pr} 0.005$ & 725.2818 & 0.6857 & -3.5 & -0.12 \\
\hline (1) $+\operatorname{Pr} 0.05$ & 728.583 & 0.5852 & 1.3 & 0.21 \\
\hline (1) $+\operatorname{Pr} 0.1$ & 714.2943 & 0,5834 & 2.0 & 0.23 \\
\hline (1) $+\operatorname{Pr} 0.5$ & 747.3512 & 0.1858 & 8.0 & 0.42 \\
\hline (1) + Sc 0.005 & 890.9848 & 0.1953 & 6.9 & 0.47 \\
\hline (1) + Sc 0.05 & 816.7284 & 0.1290 & 5.3 & 0.18 \\
\hline (1) + Sc 0.1 & 656.7735 & 0.9674 & 5.0 & 0.19 \\
\hline (1) + Sc 0.5 & 910.3302 & 0.1317 & 5.0 & 0.17 \\
\hline (1) + Y 0.005 & 706.6932 & 0.2509 & 2.8 & 0.01 \\
\hline (1) + Y 0.05 & 696.5381 & 0.395 & 1.2 & 0.05 \\
\hline (1) + Y 0.1 & 660.3804 & 0.5405 & 1.4 & 0.06 \\
\hline (1) + Y 0.5 & 607.3512 & 0.9261 & 3.0 & 0.03 \\
\hline
\end{tabular}

$$
C(T)=\frac{|\alpha(T)| S\left(T-T_{0}\right)}{m\left(\frac{d T}{d \tau}\right)} .
$$

The values of the coefficients in the equation of the temperature dependence of the specific heat for the studied systems are given in Table 2 . It should be noted that all the equations obtained are applicable only in the studied temperature range of $293-873 \mathrm{~K}$.

\section{CONCLUSION}

Based on the approximation of the experimental data for A5N aluminium [16], a comparison of the specific heat values for Al clusters with a diameter of $6 \mathrm{~nm}$ is given [17]. The temperature dependence of the heat capacity of doped alloys determines the change in solubility, i.e. the solubility of the doping metal increases with increasing temperature, 
which is in good agreement with the phase composition.

According to the obtained data, it is possible to calculate the temperature dependencies of the heat transfer coefficient for pure metals, in which the temperature dependence of heat capacity is known.

It is found that the values of heat transfer coefficients for copper, aluminium, and zinc are different.

In addition, to determine the heat capacity of doped alloys for each group, the heat transfer coefficient for the initial alloy is obtained. All obtained equations are suitable only in the studied temperature range of $293-873 \mathrm{~K}$.

\section{REFERENCES}

1. Thermophysical Properties of Materials for Nuclear Engineering: Tutorial for Students of Specialty 'Nuclear Power Plants' (Ed. P. L. Kirillov) (Obninsk: 2006), p. 182.

2. A. R. Luts and A. A. Suslina, Alyuminiy i Ego Splavy [Aluminium and Its Alloys] (Samara: Samarskiy Gosudarstvennyy Tekhnicheskiy Universitet: 2013) (in Russian).

3. R. H. Dittman and M. W. Zemansky, Heat and Thermodynamics (New Delhi: Tata McGraw Hill: 2007).

4. I. N. Ganiev, S. E. Otadzhonov, N. F. Ibrokhimov, and M. Makhmudov, High Temperature, 57: 22 (2019).

5. I. N. Fridlyander, Alyuminievye Splavy. Sostav, Svoystva, Tekhnologiya, Primenenie. Spravochnik [Aluminum Alloys: Composition, Properties, Technology, Application. A Reference Book], (Ed. I. N. Fridlyander) (Kiev: Komintekh: 2005) (in Russian).

6. V. E. Zinoviev, Thermo Physical Properties of Metals at High Temperatures. Handbook (Moscow: Metallurgiya: 1989) (in Russian).

7. Z. Nizomov, B. N. Gulov, I. N. Ganiev, R. Kh. Saidov, and A. E. Berdiev, Dokl.Akad. Nauk Resp. Tadzh., 917: 54 (2011).

8. Z. Nizomov, R. Kh. Saidov, B. N. Gulov, and Kh. Kh. Niezov, Izv. Akad. Nauk Resp. Tadzh., Otd. Fiz.-Mat., Khim., Geolog. Tekh. Nauk, 79: 3 (2016).

9. J. V. Golovenko, S. L. Gafner, L. V. Redel, and J. J. Gafner, Formation of Structure in Nanoclusters Au, Ni and Cu at Crystallization Processes. Journal Nanomaterials and Nanostructures - XXI Century, No. 3: 15 (2010).

10. A. E. Berdiev, I. N. Ganiev, H. H. Niyozov, F. U. Obidov, and R. A. Ismoilov, Materials of Electronics Engineering, 224: 17 (3) (2014).

11. V.S. Zolotorevskii and N. A. Belov, Metallovedenie Liteynykh Alyuminievykh Splavov (Metal Science of Cast Aluminum Alloys) (Moscow: Mosk. Inst. Stali Splavov: 2005) (in Russian).

12. G. K. Sigworth, AFS Trans., 7: 91 (1983).

13. W. J. Boettinger and U. R. Kattner, Metall. Trans. A, 33: 1779 (2002).

14. Y. Xiao, S. Xie, J. Liu, and T. Wang, Practical Handbook of Aluminum Technology (China, Beijing: Metallurgical Industry Press: 2005.

15. H. Feufel, T. Gödecke, H. Lukas, and F. Sommer, J. Alloys Compd., 31: 274 (1997). 